\title{
Study on Post Harvest Losses of Potato in Different Storage Conditions
}

\author{
SHRADDHA KHANAL* AND KABINDRA BHATTARAI \\ Central Campus of Technology, Tribhuvan University, Dharan, Nepal
}

\begin{abstract}
The study aimed to conduct a comparative study of three most common potato storage conditions (in-house store, in-basket store and cold store) and to find the most suitable storage condition for farmers. The experimental work involved post-harvest loss assessment and study of pattern of respiratory and reducing sugar level for sixty days storage period. Total loss was lowest (4.38\%) for cold stored potatoes and highest (13.04\%) for in-house stored potatoes. Reducing sugar accumulation was least $(0.65 \%)$ and remained almost constant throughout study period for in-house stored potatoes. Reducing sugar accumulation gradually increased and was maximum (1.04\%) for cold stored potatoes. Respiratory rate was least in cold stored potatoes which gradually decreased and reached $3.17 \mathrm{mg} \mathrm{CO} / \mathrm{kg} / \mathrm{hr}$ at the end of sixty days storage. Respiratory rate was maximum for in-basket stored potatoes which reached up to $6.55 \mathrm{mg} \mathrm{CO} / \mathrm{kg} / \mathrm{hr}$ at the end of storage. Storage loss and respiratory rate are minimum for cold stored potatoes but showed high sugar accumulation. In-house storage do not suffer from excessive sugar accumulation but storage loss is maximum of all. In case of in-basket storage, besides being cheap and feasible, there is no problem of sugar accumulation and storage losses was also significantly lower than in-house storage.
\end{abstract}

Key words: Potato, Storage losses, Respiratory loss, Moisture loss, Storage structure, Sugar accumulation

\section{Introduction}

Potato (Solanum tuberosum L.) is considered as the fourth most important crops in the world after wheat, rice and maize and is an important cash crop to address food insecurity and reduce poverty among smallholder farmers in the developing countries like Nepal (Bajracharya \& Sapkota, 2017). Potatoes belong to the group of semi perishable goods, that is, product with high natural moisture content (Kibar, 2012).

Most of the harvested potatoes are put into storage for a while before being used or distributed in the market (Ghazavi \& Houshmand, 2010). The major objectives of storage are for the future consumption, future processing, and maintenance of seed reserves. Also, it allows a better use of processing capacity, better tuning of production and consumption, and better quality of seed potatoes. To guarantee a top-quality product, storage conditions must be well controlled (Pringle et al., 2009). Low temperature storage, CA storage, storage in diffused sunlight, in situ storage, traditional clamp storage, storage in pits, storage in bamboo baskets are the major storage techniques practiced all over the world (Eltawil et al., 2006).

In Nepal, potatoes are generally planted in late September or early October. Harvesting of potatoes start as early as two months after planting (Dhital, 2000). The growers have to sell major part of their produces immediately after harvesting at a very low price due to lack of storage facilities and cash need of the growers (Hajong \& Moniruzzaman, 2014). Price of potatoes is higher in the months of September, October and November due to high demand and scarcity of seed potatoes in the market. The major types of storage practices that can be identified in Nepal are cold stores, in-house storage (storage in dark rooms), in-basket storage (storage in Doko, upon layers with wheat straw), pit storage, Netus (bamboo baskets lined with soil from inside and straw from outside with alternating layers of moist sand), separate storage buildings called kholma (better ventilated), hanging baskets *Corresponding author, email address: kshraddha1111@gmail.com etc (Dhital, 2000; Gautam, 2016). During storage, postharvest losses of potatoes occurs due to weight loss, sprouting and rotting which are directly affected by storage conditions. Potato is very sensitive to quality loss because the risk of unacceptable moisture loss, disease spread, mold infections, and insect pests attack is obvious. Potatoes undergo a gradual weight loss and quality loss which includes moisture loss, respiratory loss and changes in sugar during storage (Kuyu et al., 2019). Potato tubers lose weight in respiration, converting sugar and starches to carbon dioxide and water and losing moisture because of vapor pressure differences between the tubers and the surrounding air. Loss of moisture leads to quality loss and finally to non-marketable produce (Singh \& Kaur, 2016). In addition to the overall health condition of the tuber, variety, growth condition in the field and maturity level of tubers and storehouse temperature are the major factors influencing respiration rate and weight loss of tuber during storage (Ghazavi \& Houshmand, 2010). In this scenario, this study aimed to find the best possible storage condition of potato which improves rural farming system of Nepal.

\section{Materials and methods \\ Materials}

Procurement of potato tubers:

Potato tubers harvested under similar conditions were procured from farmers in Dhankuta, Nepal. Fresh and turgid tubers each weighing about $20 \mathrm{~g}$ were sorted out for the experimental purpose. The variety of potato was identified as Desiree.

\section{Preparation of storage structures:}

Following the traditional practice, bamboo baskets locally known as doko (average sized) and wheat straw were procured for in-basket storage and assembled. The main use of wheat straw use is its humidity regulation properties and ease of availability. To make easy accessibility for laboratory analysis and convenience during the whole work, storage environment of cold store was recreated in the laboratory 
refrigerator (Model: HSHD194, Capacity: 170 - 190 1, Power supply: 220V.50Hz, LG, India). Humidity of $85-90 \%$ was maintained using saturated potassium chloride solution $(36 \mathrm{~g}$ of $\mathrm{NaCl}$ in $100 \mathrm{~g}$ of water at $20^{\circ} \mathrm{C}$ ) (O'Brien, 2002). Temperature of $2-5^{\circ} \mathrm{C}$ was maintained. Maintenance of these conditions throughout the storage period was confirmed with the use of hygrometer (Model: J412CTH, Mextech, India) and thermometer (range: $0-100^{\circ} \mathrm{C}$ ) regularly. The chemicals used were procured from Sigma Aldrich, India.

For in-house storage and in-basket storage, temperature and relative humidity values were noted as $25-33^{\circ} \mathrm{C} / 75-85 \% \mathrm{RH}$ and $29-34^{\circ} \mathrm{C} / 80-90 \% \mathrm{RH}$ respectively. For cold storage, temperature and humidity of $2-5^{\circ} \mathrm{C} / 85-90 \% \mathrm{RH}$ was used during the course of experiment (Eltawil et al., 2006).

\section{Methods}

\section{Experimental procedure}

Each storage unit was loaded with $10 \mathrm{~kg}$ of the potato tubers. Sample unit $5 \mathrm{~kg}$ was assigned for weight loss assessment at the end of experiment while the other $5 \mathrm{~kg}$ was to be used for intermediate analysis of the tubers. For in-basket storage, tubers were arranged in layers in a bamboo basket with chopped wheat straw in between. Similarly, loading was done for in-house and cold storage units as well. Triplicate of such samples was arranged for obtaining accurate data.

The methodological approach used was pre- and post-test design. Within this context, the desired parameters were measured before commencement of the study and after the period of 2 months. Before commencement of the experiment, analysis was carried out for moisture content, sugar content and respiratory rate. During the storage period, analysis was done for the assessment of sugar and respiratory rate in every 15 days and weight of sample in each storage conditions was taken for total loss assessment at the end of 60 days of storage period. Experiment was carried out in triplicates.

\section{Analytical methods}

Moisture content of potato tubers were measured by hot air oven method. The sample was finely ground and weighted sample was kept in hot air oven for $1 \mathrm{hr}$ at $130^{\circ} \mathrm{C}$ method 925.10 (AOAC, 2005). Reducing sugar was determined by the Lane and Eynon method mentioned by (Ranganna, 2008). Total moisture loss of sample was determined by subtracting final moisture content after storage period from initial moisture content. Total loss due to moisture changes $(\%)=$ initial moisture content (\%) - final moisture content $(\%)$. After the end of storage period, the sprouts were carefully taken out of the sample and were weighted. Total loss due to sprouting $(\%)=($ weight of sprouts $\div$ total initial weight of tubers) $\times 100$.

At the end of storage period, the deteriorated or inedible tubers were visually identified. The tubers with signs of fungal growth, softened texture, black patches in the surface, foul smell etc were separated and weighted. Total loss due to deterioration $(\%)=$ (weight of deteriorated tubers $\div$ total initial weight of tubers $) \times 100$. Similarly at the end of storage period and after the segregation of sprouts and deteriorated sample, the undeteriorated tubers were finally weighted to obtain total loss. Total loss $=$ initial weight of tubers - final weight of tubers (final yield of tubers). Final yield of tubers $(\%)=($ final weight of undeteriorated tubers $\div$ initial weight $)$ $\times 100$. Total loss $(\%)=100-$ final yield of tubers $(\%)$.

After obtaining loss due to sprouts, loss due to deteriorated tubers, moisture loss and final yield of tubers, the summation of respiratory and unknown loss $(\mathrm{R}+\mathrm{U})$ was obtained. Total loss $=$ loss due to sprouts + loss due to deterioration + loss due to moisture change + loss due to respiration + unknown losses Or, (Respiratory + Unknown) losses (\%) = 100 - loss due to sprouts $(\%)$ - loss due to deterioration (\%) - moisture loss (\%) - final yield of tubers $(\%)$.

For the Analysis of respiratory rate: Initially, air was made free of $\mathrm{CO}_{2}$ by passing the air through $40 \%$ potassium hydroxide solution. Then it was passed through the respiring potatoes where $\mathrm{CO}_{2}$ respired by the produce was collected in calcium hydroxide solution. Thus collected $\mathrm{CO}_{2}$ concentration was determined by by gravimetric method (i.e. by taking weight of calcium carbonate precipitated) which was finally related with the total $\mathrm{CO}_{2}$ produced (Hans et al., 2011).

\section{Statistical analysis}

Statistical calculations were performed in Microsoft Office Excel 2007. For the significance analysis, the data were analyzed by one-way ANOVA (no blocking) using GenStat Release 12.1 (2009), VSN International, UK. Means were compared using LSD at 5\% level of significance. Fishner's protected LSD was used for the multiple comparison (Payne, 2007).

\section{Results and Discussions}

\section{Post-harvest loss during storage}

Post harvest loss of Potato in different storage conditions was studied. Study was done in three storage conditions representing $\mathrm{A}, \mathrm{B}$, and $\mathrm{C}$ meaning in-house stored, in-basket stored and cold stored potatoes respectively. Storage losses was categorized as sprout loss, Deterioration loss, Moisture loss, Respiratory and Unknown $(\mathrm{R}+\mathrm{U})$ loss. The overall results of storage losses of potato in different storage conditions is given in Fig 1 (graphical presentation) and Table 1 .

\section{Loss due to sprout}

At the end of storage period, for in-house storage, loss due to sprouting was found to be $(0.18 \pm 0.0015) \%$ and that was $(0.27 \pm 0.05) \%$ for in-basket storage while in cold stored potatoes, no any signs of sprout growth was seen (Table 1). The results are significantly $(p<0.05)$ different with each other. The significantly greater loss in in-basket storage is due to the high temperature of storage $\left(31^{\circ} \mathrm{C}\right)$ than ambient $\left(29^{\circ} \mathrm{C}\right)$ as sprouting phenomenon is dependent mainly on the temperature. While in cold store, temperature was between $2^{\circ} \mathrm{C}-5^{\circ} \mathrm{C}$ which didn't have any sprout growth. In the work carried out by Ezekiel and Dahiya (2002) for room storage, sprout weight was $0.47 \mathrm{~g}$ while for heap storage, that was $0.63 \mathrm{~g}$ per $100 \mathrm{~g}$ when stored for 127 days. Furthermore, in the 


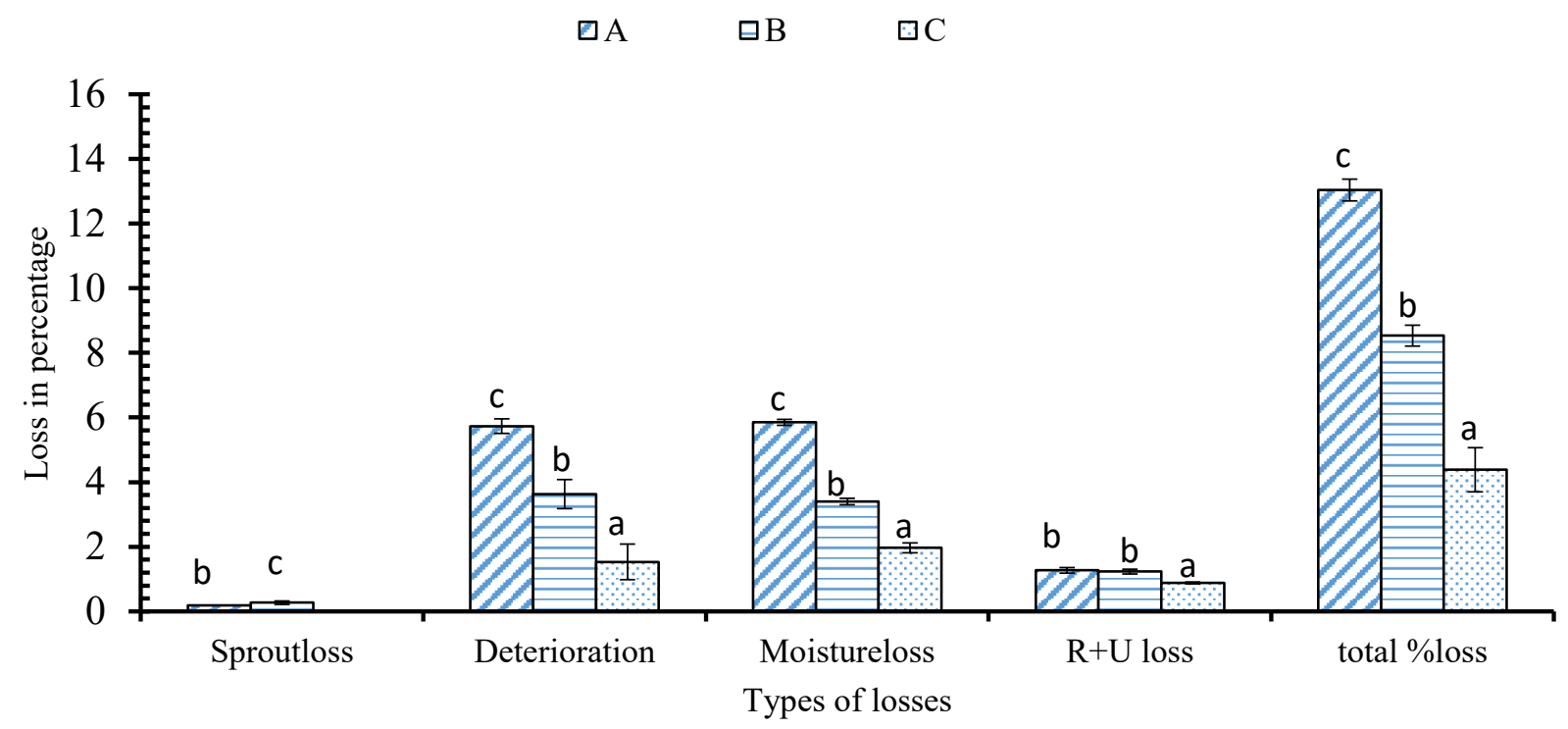

Figure 1. Comparison of total storage loss in three storage conditions. Here, A, B, and C denotes in-house stored, in-basket stored and cold stored potatoes, respectively. Vertical error bars represent standard deviation of values from mean $(n=3)$. The same letters above the error bar signify no significant difference.

work done by Kaul and Mehta (1999) weight loss due to sprouting is $0.67 \%$ for Kufri Sinduri and $0.6 \%$ for Kufri Phulwa during 15 weeks of storage. The obtained values are higher than that obtained for Desiree variety in this study. This would be due to the fact that dormancy and extent of sprouting depends on variety. Also, since the sprout depends on the tuber materials for growth, if there are several sprouts on the tuber, an inter-sprout competition for growth factors will be imposed by the size of the tuber. With fairly large tubers, no effect of size will be noticeable, but with decreasing size, as size is smaller, growth of sprouts will be lesser (Carli \& Mihovilovich, 2010). In this research, tuber sizes used for experimentation were very small i.e. around 20 $\mathrm{g}$ which might have resulted in lower growth of sprouts.

\section{Loss due to deterioration}

Loss due to spoilage or deterioration of tubers after 60 days of storage was found to be $(5.73 \pm 0.22) \%$ for in-house storage, $(3.63 \pm 0.44 \%$ for in-basket storage and $(1.55 \pm 0.55)$ $\%$ for cold stored potatoes (Table 1). The amount of deterioration was significantly $(\mathrm{p}<0.05)$ different in all three cases. The deteriorative loss in traditional storage system was more than that of cold due to moth attack in in the former. Among the insects, tuber moth is common in potatoes stored in non-refrigerated storage. The larval damage results in direct weight loss and tuber moth infestation greatly reduces market value of the tubers which was unlikely found in cold stored potatoes (Keasar et al., 2005). Percentage of deterioration in in-basket storage was less than in in-house storage even among the traditional storage systems because dry wheat straw prevents condensation of transpired vapour on tuber surface. Thus prevents excessively wet condition within the storage area. This avoids the development of fungal diseases that normally thrive under humid and warm conditions (Mutandwa \& Gadzirayi, 2007). Straw absorbs condensed water produced by the tubers respiration, which might otherwise enhance the presence of microorganisms (Knutsson, 2012). According to Ezekiel and Dahiya (2002), losses in room storage due to rotting was $4.7 \%$ while that for heap storage was $3.8 \%$. This is similar to the result obtained in this research. However, Singh et. al., (2014) reported that loss due to rotting in traditional storage system is about 10-12 $\%$ whereas, Hossain and Miah (2009), reported that in cold stores, the weight loss due to rotting was $34 \%$ in nine months The variability of the results among various authors depends on various pre harvest factors, factors during harvest and the cultivar used for the experimentation itself.

Table 1

Post-harvest loss of Potato in different storage conditions.

\begin{tabular}{lccccc}
\hline \multicolumn{1}{c}{ Storage type } & Sprout loss (\%) & $\begin{array}{c}\text { Deterioration } \\
\text { loss (\%) }\end{array}$ & $\begin{array}{c}\text { Moisture loss } \\
(\%)\end{array}$ & R+U loss (\%) & Total loss (\%) \\
\hline In-house storage (A) & $0.18 \pm 0.01^{\mathrm{b}}$ & $5.73 \pm 0.22^{\mathrm{c}}$ & $5.85 \pm 0.09^{\mathrm{c}}$ & $1.28 \pm 0.08^{\mathrm{b}}$ & $13.04 \pm 0.33^{\mathrm{c}}$ \\
In-basket storage (B) & $0.27 \pm 0.05^{\mathrm{c}}$ & $3.63 \pm 0.44^{\mathrm{b}}$ & $3.40 \pm 0.01^{\mathrm{b}}$ & $1.24 \pm 0.07^{\mathrm{b}}$ & $8.54 \pm 0.32^{\mathrm{b}}$ \\
Cold storage (C) & 0 & $1.55 \pm 0.55^{\mathrm{a}}$ & $1.96 \pm 0.15^{\mathrm{a}}$ & $0.88 \pm 0.02^{\mathrm{a}}$ & $4.38 \pm 0.68^{\mathrm{a}}$ \\
\hline
\end{tabular}

The values are the means of triplicate. Numbers after \pm are standard deviation of the data $(n=3)$. The same letters in the superscript in a column signify no significant difference between the samples. 
In our study, Desiree variety was used for experiment is one of the most disease and damage resistant variety showing resistance to dry rot, late blight, potato virus $\mathrm{M}$ and $\mathrm{X}$, and other environmental stress factors leading to deterioration (AHDB, 2020). This fact might have resulted in lower deteriorative loss results.

\section{Loss due to moisture changes}

Loss in moisture content was $(5.85 \pm 0.09) \%$ for in-house storage and it was $(3.4 \pm 0.1) \%$ for in-basket storage and $(1.96 \pm 0.15) \%$ for cold stored potatoes (Table 1$)$. The values are significantly $(\mathrm{p}<0.05)$ different with each other. The moisture loss in cold storage was significantly lower than inhouse and in-basket storage system the traditional high temperature storage system because of maintenance of appropriate relative humidity in cold storage (85-90\%) which helps in prevention of desiccation. Among the traditional storage structures as well, in-basket storage suffers lower loss in moisture than in-house storage because the straw prevents further loss of moisture from potatoes (Kibar, 2012). Similar results were obtained by Kaul and Mehta (1999) for room temperature storage for Kufri Chandramukhi and Kufri Jyoti varieties. Also, the results obtained by Ezekiel and Dahiya (2002) for cold stored potatoes are in close agreement with the result obtained in this study.

\section{Loss due to respiration and unknown loss}

Loss due to respiration was calculated through empirical method. All other known losses and final tuber yield was deducted from initially stored potatoes to obtain total respiratory loss. Thus, it is understood that the obtained value not only represents respiratory loss but may also include some other unknown loss which could not be quantified from this experiment. So, loss due to respiration is considered along with unknown losses. Respiratory and unknown loss $(\mathrm{R}+\mathrm{U})$ loss were $(1.28 \pm 0.08) \%$ of the total weight of stored commodity for in -house storage and that was $(1.24 \pm 0.07)$ $\%$ for in-basket storage (Table 1). Similarly, for cold stored potatoes, the value was $(0.88 \pm 0.02) \%$. As the rate of respiration is lowest for cold stored potatoes, the respiratory loss is also obviously lower. Although the respiration rate of in-basket stored potatoes is higher, the resultant $(\mathrm{R}+\mathrm{U})$ value seems to be lower than in-house storage due to the contribution of unknown losses which is lower in in-basket storage.

\section{Total \% loss during storage}

Total loss during storage was found to be $(13.04 \pm 0.33) \%$ for in-house storage. Similarly, total loss was (8.54 \pm 0.32$) \%$ for in-basket storage and for cold storage, total loss was (4.38 $\pm 0.68) \%$ (Table 1 ). Thus, all the three values are significantly different with each other with loss in cold storage being minimum and that at in-house storage being maximum. Lesser efficiency of traditional storage systems is mainly because of loss due to rotting and moisture change rather than loss due to sprouting and respiration. While among the traditional storage systems, in-basket storage is found to be more efficient than in-house storage in terms of total loss at the end. The data obtained shows close resemblance with that observed by several other researchers. Kaul and Mehta (1999) observed that the storage loss in their experimental store was $11.64 \%$ for Kufri Chandramukhi and $11.22 \%$ for Kufri Lauvakar. Tiwari and Chourasia (2013) have also mentioned that, the storage losses in potato stored in cold storages account for 3-10\% in the form of rotting, cold injury, weight loss, sprouting, etc. which agrees with the result obtained in this study.

\section{Result of respiration rate and reducing sugar}

The post-harvest loss study was also focused on the trend of respiration and reducing sugar changes during the storage, and the result is given in Fig 2 (a) and Fig 2 (b) respectively.

\section{Change in respiration rate during storage}

As shown in Figure 2(a), the initial rate of respiration is 5.42 $\mathrm{mgCO}_{2} / \mathrm{kg} / \mathrm{hr}$. Statistical results showed that for in-house storage, respiration rate significantly decreased $(p<0.05)$ for up to 30 days of storage while it significantly increased in $45^{\text {th }}$ and $60^{\text {th }}$ days of storage.

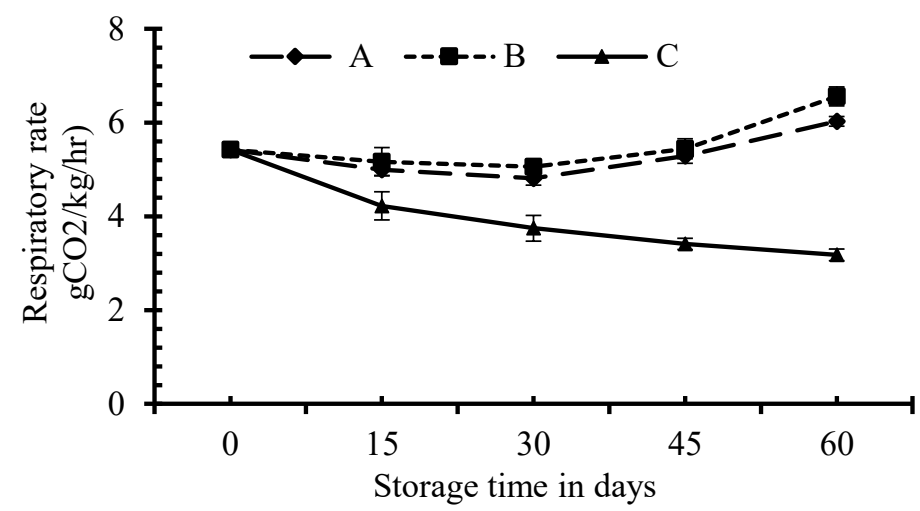

Figure 2a. Trend of respiration rate change during two months of storage. Here, A, B, and C represents in-house stored, in-basket stored and cold stored potatoes respectively. The vertical error bars represents standard deviation of values from mean $(n=3)$.

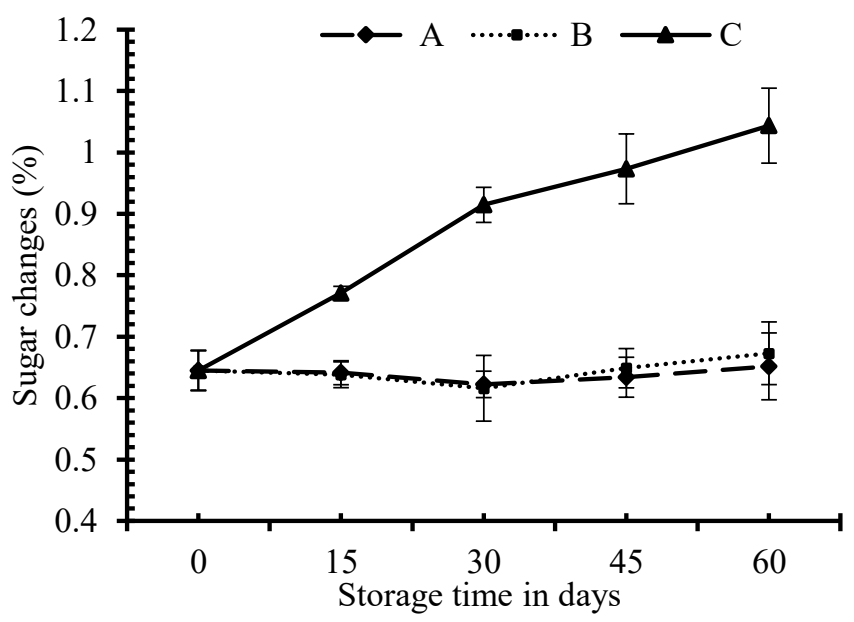

Figure 2b. Trend of reducing sugar changes during two months of storage. Here, A, B, and C represents in-house stored, in-basket stored and cold stored potatoes respectively. The vertical error bars represents standard deviation of values from mean $(n=3)$. 
For in-basket storage, there was slight but non -significant decrease in respiration rate for up to $30^{\text {th }}$ day of storage which again significantly $(\mathrm{p}<0.05)$ increased at $45^{\text {th }}$ and $60^{\text {th }}$ day of storage. This increase in respiration rate after $45^{\text {th }}$ and $60^{\text {th }}$ day of storage in in-house and in-basket storage is due to onset of sprouting phenomenon. As sprouting starts, the resultant rate of respiration increases (Mikitzel \& Knowles, 2011). Before the onset of sprouting, the tubers are in dormant phase with slight increase and rather constant respiration rate. Meanwhile, during dormancy, the endogenous metabolic rate of tubers is at minimum and therefore the dry matter losses are correspondingly reduced leading to constant respiration rate (Claassens, 2002). For cold storage, rate of respiration significantly decreased with storage time which is due to the decreasing metabolism in low temperature storage. Fennir et al. (2005) observed that the respiration rate to be gradually declining from 4.5 to $3.1 \mathrm{mg} \mathrm{CO} / \mathrm{kg} / \mathrm{hr}$ in the period of 44 days at cold storage temperature and this result is in line with our findings.

\section{Change in reducing sugar during potato storage}

As shown in Fig 2b, for in-house storage and in-basket storage, there was no significant change in sugar level during the storage period but a very slight and non-significant decrease in sugar level was observed up to 30 days of storage. After 30 days, further very slight but non-significant increase in sugar level was seen. When potatoes containing sugar are placed at higher temperatures, the slow and slight disappearance of sugar is because sugar is partly used up in respiration, and partly reconverted to starch (the disappearance of the sugar can't be all accounted by the amount of carbondioxide exhaled) (Yamdeu \& Gupta, 2015). Physiological changes in a potato upon initiation of sprouting will cause increases in reducing sugar (Mani \& Hannachi, 2015). In this study, the slight increase in sugar level after 30 days of storage is also because of accumulation of sugar due to sprouting. Abong et al. (2009), in his study on eight different potato cultivars obtained similar results. For cold stored potatoes, results showed that reducing sugar was found to increase significantly $(\mathrm{p}<0.05)$ with storage period in all the cultivars. The amount of reducing sugar increased is due to the enzymatic conversion of starch and sucrose to reducing sugar and decreased respiration rate (Amjad et al., 2020). The activity of the enzyme invertase, which hydrolyzes sucrose is high at lower storage temperature (Singh \& Kaur, 2009). The activity of invertase was found to increase about 2 to 12 folds from harvesting to cold stored conditions (Karim et al., 2008).

\section{Conclusions}

Among the three storage conditions (in-house store, in-basket store and cold store) conducted during this study, cold stored $\left(2-5^{\circ} \mathrm{C} / 85-90 \% \mathrm{RH}\right)$ potatoes resulted minimum storage loss while in-house stored $\left(25-33^{\circ} \mathrm{C} / 75-85 \% \mathrm{RH}\right)$ potato showed maximum storage loss. Cold stored potatoes are found unsuitable for food purposes due to higher sugar accumulation as compared to other two conditions. In-basket storage $\left(29-34^{\circ} \mathrm{C} / 80-90 \% \mathrm{RH}\right)$ was found to be the best storage condition for food purpose. In case of seed purpose, where sugar accumulation is not a problem, cold storage $\left(2^{\circ}\right.$ $5^{\circ} \mathrm{C} / \mathrm{RH} 85-95 \%$ ) would be suitable storage condition. The outcome of this study may be useful for farmers for potato storage and the respective suitable conditions may be selected to store potato as per Food and Seed purposes.

\section{References}

Abong, G. O., Okoth, M. W., Karuri, E. G., Kabira, J. N., \& Mathooko, F. M. (2009). Levels of reducing sugars in eight Kenyan potato cultivars as influenced by stage of maturity and storage conditions. Journal of Animal \& Plant Sciences, 2(2), 76-84.

AHDB. (2020). Desiree. In Potato Variety Database. Scotland: Agriculture and Horticulture Development Board.

Amjad, A., Javed, M. S., Hameed, A., Hussain, M., \& Ismail, A. (2020). Changes in sugar contents and invertase activity during low temperature storage of various chipping potato cultivars. Food Sci. Technol, 40(2), 340345.

AOAC. (2005). Official Methods of Analysis (18th ed.). Washington DC: Association of Official Analytical Chemists.

Bajracharya, M., \& Sapkota, M. (2017). Profitability and productivity of potato (Solanum tuberosum) in Baglung district, Nepal. Agriculture and Food Security, 6(47), 18.

Carli, C., \& Mihovilovich, E. (2010). Assessment of dormancy and sprouting behavior of CIP elite and advanced clones under different storage conditions in Uzbekistan. Potato research, 53(4), 313-323.

Claassens, M. M. J. (2002). Carbohydrate metabolism during potato tuber dormancy and sprouting. (PhD Dissertation). Wageningen University, Wageningen, Netherlands.

Dhital, B. K. ( 2000). Diffused Light Storage of Seed Potatoes in the Hills of Nepal in Relation to Seed Tuber Physiology, Production Environment, and SocioEconomics. (Ph.D. Thesis). University of Newcastle upon Tyne.

Eltawil, M. A., Samuel, D. V. K., \& Singhal, O. P. (2006). Potato storage technology and store design aspects. Agricultural Engineering International: the CIGR Ejournal, 8(11), 1-15.

Ezekiel, R., Dahiya, P. S., \& Shekhawat, G. S. (2002). Traditional methods of potato storage in the majwa region of madhya pradesh. Journal of Indian Potato Association, 3(1), 21-28.

Fennir, M., Landry, J. A., \& Raghavan, V. G. S. (2005). Respiration rate of potatoes (Solanum tuberosum L.) as affected by soft rot (Erwinia carotovora ) and determined at various storage temperatures. West Indian Journal of Engineering, 27(2), 1-18.

Gautam, I. P. (2016). Seed and Ware Potato Storage and processing status in Nepal (Report No.2). National Potato Research Program, Khumaltar, Nepal.

Ghazavi, M. A., \& Houshmand, S. (2010). Effects of mechanical damage and temperature on potato respiration rate and weight loss. World Applied Sciences Journal, 8(5), 647-652.

Hajong, P., \& Moniruzzaman, M. (2014). Storage system of potato in bangladesh. Universal Journal of Agricultural Research, 2(1), 11-17.

Hans, S. J., Yoo, M., Kim, D. W., \& Wee, J. H. (2011). Carbondioxide capture using calcium hydroxide aqueous solution as the absorbent. J. Energ. Fuel, 25(8), 38253834.

Hossain, M. A., \& Miah, M. A. M. (2009). Post harvest losses and technical efficiency of potato storage systems in 
Bangladesh (Report No. 8). Bangladesh Agricultural Research Institute, Bangladesh.

Karim, M. R., Khan, M. M. H., Uddin, M. S., Sana, N. K., Nikkon, F., \& Rahman, M. H. (2008). Studies on the sugar accumulation and carbohydrate splitting enzyme levels in post harvested and cold stored potatoeS. J. biosci., 16, 98-99.

Kaul, H. N., \& Mehta, A. (1999). Non refrigerated storage of potatoes in plains. In Storage of potatoes in India (1st ed.). Shimla-171 001, HP (India) Central Potato Research Institute.

Keasar, T., Kaalish, A., Becher, O., \& Steinberg, S. (2005). Spatial and temporal dynamics of potato tuberworm (Lepidoptera: Gelechiidae) infestation in field-stored potatoes. J. Econ Entomol, 98(1), 222-228.

Kibar, H. (2012). Design and management of postharvest potato (Solanum Tuberosum L.) storage structures. $J$. Sci. Tech., 2(1), 23-48.

Knutsson, J. (2012). Long-term storage of starch potato and its effect on starch yield. (M. Sc. Thesis). Swedish University of Agricultural Sciences, Sweden.

Kuyu, C. G., Tola, Y. B., \& Abdi, G. G. (2019). Study on post-harvest quantitative and qualitative losses of potato tubers from two different road access districts of Jimma zone, South West Ethiopia. Heliyon, 5(8), e02272.

Mani, F., \& Hannachi, C. (2015). Physiology of potato sprouting. J. new sci., 17(2), 591-602.

Mikitzel, L. J., \& Knowles, N. R. (2011). Changes in respiratory metabolism during sprouting of aged seedtubers. Canadian Journal of Botany, 68(8), 1619-1626.

Mutandwa, E., \& Gadzirayi, C. T. (2007). Comparative assessment of indigenous methods of sweet potato preservation among smallholder farmers: Case of grass, ash and soil based approaches in Zimbabwe African Studies Quarterly, 9(3), 85-98.

O'Brien, F. E. M. (2002). The control of humidity by saturated salt solutions. Journal of Scientific Instruments, 25(3), 73.

Pringle, P., Pringle, R., Bishop, C., \& Clayton, R. (2009). Physiology. In Potatoes Postharvest. UK: CAB international.

Ranganna, S. (2008). Handbook of Analysis and Quality Control for Fruits and Vegetable Products (2nd ed.). New Delhi: Tata McGraw-Hill Publishing Company Limited.

Singh, B., Mehta, A., Raigond, P., \& Rawat, S. (2014). Potato storage systems in india. ICAR, India: Central Potato Research Institute.

Singh, J., \& Kaur, L. (2016). Post harvest storage of potatoes. In Advances in Potato Chemistry and Technology (2nd ed.). USA: Academic Press.

Tiwari, V. N., \& Chourasia, M. K. (2013). Studies on storage of potato (Solanum Tuberosum l.) in India. Paper presented at the 9th All India Peoples's Technology congress, Science City Kolkata.

Yamdeu, J. H. G., \& Gupta, P. H. (2015). Effect of storage temperature on carbohydrate metabolism and development of cold-induced sweetening in Indian potato (Solanum tuberosum l.) varieties. Journal of Food Biochemistry, 40(1), 71-83. 